\title{
PENGARUH KONSUMSI MINUMAN LOKAL TERHADAP FLOUR ALBUS DAN AKNE VULGARIS PADA SISWI SMA DI KAB. KOLAKA
}

\author{
Arliatin $^{1}$, Andi Nurlinda ${ }^{2}$, H. A. Muh. Multazam ${ }^{3}$ \\ ${ }^{1}$ Universitas Cokroaminoto Makassar \\ ${ }^{2}$ Universitas Cokroaminoto makassar \\ ${ }^{3}$ Universitas Cokroaminoto Makassar
}

(Alamat korespondensi : Arlyaakmar@gmail.com/ 085333609933)

Sekitar $85 \%$ remaja pernah terkena akne vulgaris Penelitian ini bertujuan untuk menganalisis Pengaruh Konsumsi Minuman Lokal Terhadap tanda dan gejala flour albus dan akne vulgaris pada siswi SMA di Kab. Kolaka.Penelitian ini merupakan penelitian eksperimen metode eksperimen semu dengan rancangan Two Group Pretest-Postest Desain. Populasi semua siswi SMA yang mengalami flour albus dan akne vulgaris dengan jumlah sampel sebanyak 20 responden yang dibagi menjadi 2 kelompok yaitu 10 sampel eksperimen yang diberikan minuman lokal yang terdiri dari 3 buah yang di mix yaitu nangka, melon, kersen dan 10 sampel kontrol. Penelitian ini diolah menggunakan sistem komputerisasi dengan bantuan program SPSS. Uji Analisis data yang digunakan adalah Uji NPar-Test. Hasil penelitian yang diperoleh adalah ada pengaruh konsumsi minuman lokal terhadap penurunan tanda dan gejala flour albus dimana nilai $\mathrm{p}=0,000 \quad(\mathrm{p}<0,05)$, ada pengaruh pengaruh konsumsi minuman lokal terhadap tanda dan gejala flour albus dimana nilai $p=0,001$ $(\mathrm{p}<0,05)$, kesimpulan penelitian ini adalah ada pengaruh konsumsi minuman lokal terhadap flour albus dan akne vulgaris pada siswi SMA di Kab. Kolaka.

Kata kunci: Minuman Lokal, flour albus, akne vulgaris,

\section{PENDAHULUAN}

Masalah flour albus adalah masalah yang sejak lama menjadi persoalan bagi kaum wanita. Keputihan adalah keluarnya sekret atau cairan dari vagina. Sekret tersebut dapat bervariasi dalam konsistensi, warna dan bau. Keputihan dapat diartikan sebagai semacam lendir yang keluar terlalu banyak, warnanya putih seperti sagu kental dan agak kekuning-kuningan, jika lendir ini tidak terlalu banyak, tidak menjadi persoalan. Umumnya wanita yang menderita keputihan mengeluarkan lendir tersebut terlalu banyak dan menimbulkan bau yang tidak enak. (Kurnia, 2010)

Flour albus menyerang sekitar $50 \%$ populasi perempuan dan mengenai hampir pada semua umur. Data penelitian tentang kesehatan reproduksi wanita menunjukkan $75 \%$ wanita di dunia menderita keputihan paling tidak sekali seumur hidup dan $45 \%$ diantaranya bisa mengalaminya sebanyak dua atau lebih. Kejadian keputihan Di Indonesia mencapai $75 \%$ wanita mengalami keputihan yang disebabkan oleh bakteri dan jamur Candida albicans ( komariah, 2015).

Berdasarkan data WHO (2007), 25\%-50\% candidiasis albican, 20\%-40\% bacterial vaginosis dan 5\%-15\% trichomoniasis. Wanita di Eropa yang mengalami Keputihan sekitar 25\%.Menurut BKKBN (2009). di Indonesia sebanyak $75 \%$ wanita pernah mengalami Keputihan minimal satu kali dalam hidupnya dan $45 \%$ diantaranya bias mengalami keputihan sebanyak dua kali atau lebih (Nurmah, 2012).

Flour albus disebabkan oleh banyak faktor salah satunya adalah bakteri, candida. albicans yang dapat 
dihambat oleh vitamin A. sedangkan buah merupakan salah satu sumber vitamin A yang tinggi adapun manfaat yang terkandung dalam buah nangka, melon dan kersen adalah kadar vitamin A dan $\mathrm{C}$ yang tinggi yang berfungsi sebagai anti bakteri, membantu pembentukan jaringan tubuh,, memelihara kesehatan kulit, meningkatkan daya tahan tubuh, anti kanker dll (Rahayu dan Putik 2012 ).

Akne vulgaris adalah penyakit peradangan menahun pada folikel pilosebasea Sekitar 85\% remaja pernah terkena akne vulgaris dan sering berlanjut sampai dewasa keluhan akne vulgaris setiap tahun, khususnya rentang usia 1519 tahun. akne merupakan penyakit kulit yang tersering dan dialami oleh segala usia dan biasanya dialami oleh para remaja. Sebanyak 80-90\% remaja menderita akne. (Nisa, 2015)

Vitamin merupakan senyawa organic kompleks yang di butuhkan tubuh dalam jumlah sedikit, meskipun dibutuhkan sedikit tetapi sangat penting untuk pertumbuhan dan mempertahankan kesehatan. Vitamin bekerja dengan dengan cara mengaktifkan reaksi kimia metabolism energi. Sistem imunitas tubuh memiliki fungsi yaitu membantu memperbaiki DNA manusia mencegah infeksi yang disebabkan oleh jamur, bakteri, virus, dan organisme lain serta menghasilkan antibodi (sejenis protein yang disebut immunoglobulin) untuk memerangi serangan bakteri dan virus asing kedalam tubuh. Tugas sistem imun adalah mencari dan merusak invader (penyerbu) yang membahayakan tubuh manusia (Fatmah, 2012)

Minuman lokal ini terdiri dari tiga kombinasi buah yang telah dipilih untuk dijadikan bahan pembuatan ekstrak minuman lokal. Salah satu buah asli Indonesia yang masuk dalam kriteria bahan dasar pembuatan minuman lokal ini adalah buah nangka, buah melon dan kersen.

Berdasarkan survei pendahuluan yang dilakukan peneliti dengan metode wawancara di SMAN 1 Samaturu Kab.Kolaka yang dilakukan terhadap 118 siswi kelas X dan XI, hasilnya yaitu dari 118 siswi tersebut gejala yang paling utama ketika mengalami flour albus adalah merasa tidak nyaman akibat cairan yg keluar dari vagina, merasa gatal sewaktu-waktu, dan keluhan lain adalah masalah timbulnya acne vulgaris yang sangat membuat para siswi tidak nyaman. Berdasarkan uraian latarbelakang maka rumusan masalah pada penelitian ini adalah adakah pengaruh konsumsi minuman lokal terhadap flour albus dan akne vulgaris pada siswi SMA di kab. kolaka?

\section{BAHAN DAN METODE}

Penelitian ini menggunakan metode penelitian eksperimen atau percobaan (Experiment Research), yang bertujuan untuk mengetahui suatu gejala atau efek yang timbul sebagai akibat dari adanya perlakuan tertentu.

Penelitian ini akan dilaksanakan di SMAN samaturu kab.kolaka pada tanggal 1 agustus - 20 september 2017. Populasi adalah keseluruhan sumber data yang diperlukan dalam suatu penelitian (Saryono, 2011). Populasi dalam penelitian ini adalah semua siswi kelas $X$ dan XI SMAN 1 Samaturu Kab Kolaka sebanyak 118 siswi. Teknik Pengambilan sampel dalam penelitian ini menggunakan kuota sampling, dimana pengambilan sampel dari populasi di lakukan dan di tentukan dengan kriteria:

a. Kriteria inklusi

1. Siswi yang masih aktif sekolah

2. Mengalami flour albus

3. mengalami akne vulgaris dan tidak dalam proses perawatan

4. bersedia menjadi responden

b. Kriteria Eklusi:

1. Tidak Bersedia menjadi responden

2. alam pengobatan flour albus

3. Dalam pengobatan akne vulgaris

\section{Pengolahan Data}


Pengolahan data dilakukan secara manual (dengan mengisi lembar observasi yang disediakan), selanjutnya menggunakan bantuan program SPSS for Windows dengan urutan sebagai berikut:

\section{Selecting}

Seleksi merupakan pemilihan untuk mengklarifikasi data menurut kategori.

Editing dilakukan untuk meneliti setiap daftar pernyataan yang sudah diisi, editing meliputi kelengkapan pengisian, kesalahan pengisian dan konsistensi dari setiap jawaban.

2. Koding

Koding merupakan tahap selanjutnya dengan member kode pada jawaban dari responden tersebut.

3. Tabulasi Data

Setelah dilakukan kegiatan editing dan koding dilanjutkan dengan mengelompokkan data ke dalam suatu tabel menurut sifat-sifat yang dimiliki sesuai dengan tujuan penelitian.

\section{Analisa Data}

Setelah dilakukan tabulasi data, analisa data yang diperoleh kemudian diolah dengan manggunakan komputer selanjutnya disajikan dalam bentuk tabel distribusi. Analisa data yang digunakan adalah:

a. Analisa univariat

Pada analisis univariat, data yang diperoleh dari hasil pengumpulan data dapat disajikan dalam bentuk tabel distribusi frekuensi, ukuran tendensi sentral (mean, median, modus) atau grafik (Saryono \& Anggraeni, 2013). Pada penelitian ini variabel independen, dependen, confounding, moderator dianalisis dengan menggunakan statistik deskriptif.

b. Analisa Bivariat

Menganalisa data yang dilakukan terhadap 2 variabel yang diduga berpengaruh. Dalam penelitian ini untuk mengetahui pengaruh antara variabel dependen (Kadar HB) dengan variabel independen (Pemberian serbuk minuman lokal). Analisa data dilakukan dengan menggunakan komputer dengan program SPSS.

Analisa data yang dilakukan terhadap tiap-tiap variabel independen dan variabel dependen dengan menggunakan uji statistik yang digunakan adalah Uji PairedSample $T$ Test, setelah uji normalitas sebaran data normal, tapi jika tidak terpenuhi maka yang dipakai adalah uji alternatif,yaitu uji Wilcoxon. Apabila nilai $\mathrm{p}>\alpha$ $(0,05)$, maka Ho diterima Ha ditolak, artinya pemberian serbuk minuman lokal tidak berefek terhadap Kadar $\mathrm{Hb}$ ibu hamil di puskesmas kassi-kassi makassar. Jika $\mathrm{p}<0,05$, maka Ho ditolak dan Ha diterima, artinya pemberian serbuk minuman lokal berefek terhadap Kadar $\mathrm{Hb}$ ibu hamil di puskesmas kassi-kassi makassar.

\section{HASIL PENELITIAN}

1. Analisis univariat

Tabel 3 Distribusi Responden Berdasarkan Flour Albus pada Siswi SMA di Kab. Kolaka

\begin{tabular}{|c|c|c|c|c|}
\hline \multirow{2}{*}{$\begin{array}{c}\text { Flour } \\
\text { Albus }\end{array}$} & \multicolumn{2}{|c|}{ Eksperimen } & \multicolumn{2}{c|}{ Kontrol } \\
\cline { 2 - 5 } & Pre & Post & Pre & Post \\
\hline Mengalami & 10 & 2 & 10 & 10 \\
\hline $\begin{array}{c}\text { Tidak } \\
\text { Mengalami }\end{array}$ & 0 & 8 & 0 & 0 \\
\hline Total & 10 & 10 & 10 & 10 \\
\hline
\end{tabular}

Tabel 3 menunjukkan bahwa distribusi frekuensi responden berdasarkan karakteristik Tanda dan gejala flour albusi di mana terhadap 10 responden pada kelompok eksperimen, $10(100 \%)$ orang dalam kategori mengalami flour albus dan Pada Post tes 8 responden mengalami penurunan tanda dan gejala flour albus sedangkan pada kelompok kontrol pada tahap pretest terhadap $10 \quad(100 \%)$ responden 
dalam kategori mengalami flour albus dan Pada Post tes 10 responden Tidak Mengalami penurunan yang berarti.

Tabel 4 Distribusi Responden Berdasarkan Akne Vulgaris pada Siswi SMA di Kab. Kolaka $(n=20)$

\begin{tabular}{|c|c|c|c|c|}
\hline \multirow{2}{*}{$\begin{array}{c}\text { Akne } \\
\text { Vulgaris }\end{array}$} & \multicolumn{2}{|c|}{$\begin{array}{c}\text { Eksperime } \\
n\end{array}$} & \multirow{2}{*}{\begin{tabular}{|c|} 
Kontrol \\
Pre \\
post
\end{tabular}} & \multirow{2}{*}{ Post } \\
\hline & Pre & Post & & \\
\hline $\begin{array}{c}\text { Mengalam } \\
\text { i }\end{array}$ & 10 & 3 & $\begin{array}{l}10 \\
10\end{array}$ & 0 \\
\hline $\begin{array}{c}\text { Tidak } \\
\text { Mengalam } \\
\mathrm{i} \\
\end{array}$ & 0 & 7 & 0 & 0 \\
\hline Total & 10 & 10 & $\begin{array}{l}10 \\
10\end{array}$ & 0 \\
\hline
\end{tabular}

Tabel 4 menunjukkan bahwa distribusi frekuensi responden berdasarkan karakteristik Akne vulgaris di mana terhadap 10 responden pada kelompok eksperimen,10 (100\%) orang dalam kategori Akne vulgaris dan Pada Post tes 7 responden mengalami penurunan tanda dan gejala akne vulgaris sedangkan pada kelompok kontrol pada tahap pre tes terhadap 10 $(100 \%)$ responden dalam kategori dan Pada Post tes 10 responden tidak mengalami penurunan yang berarti

2. Analisis Bivariat

Tabel 6 Kelompok Intervensi dan Kelompok Kontrol Pengaruh Konsumsi Minuman Lokal Terhadap Flour Albus Pada Siswi SMA di Kab. Kolaka

\begin{tabular}{|c|c|c|c|c|c|c|c|c|c|}
\hline \multirow{3}{*}{$\begin{array}{c}\text { Flou } \\
\text { r } \\
\text { albu } \\
\text { s }\end{array}$} & \multicolumn{3}{|c|}{ Eksperimen } & & \multicolumn{4}{|c|}{ Kontrol } & \\
\hline & Pre & \multicolumn{2}{|c|}{ Post } & & \multicolumn{2}{|c|}{ Pre } & \multicolumn{2}{|c|}{ Post } & \\
\hline & $\mathrm{n} \%$ & $\mathrm{n}$ & $\%$ & & $\mathrm{n}$ & $\%$ & & & \\
\hline $\mathrm{Ya}$ & 1010,0 & 2 & 0 & $\begin{array}{c}0,00 \\
0\end{array}$ & & 00 & 10 & 0 & $\begin{array}{r}0,6 \\
9\end{array}$ \\
\hline & 0,00 & & 80,0 & & 0 & 0 & U & & \\
\hline
\end{tabular}

Tabel 6 Menunjukkan bahwa siswi SMA di KAb. kolaka pada kelompok eksperimen pada saat pretest sebanyak
$10(100 \%)$ responden mengalami flour albus dengan standart devisiasinya sebanyak 0,738 dan pada saat posttest pada kelompok eksperimen terdapat 8 $(80,0 \%)$ responden mengalami penurunan flour albus dan ada 2 responden tidak mengalami Penurunan flour albus dan standart devisiasi pada kelompok posttest sebanyak 1,317

Sedangkan pada kelompok kontrol Menunjukkan bahwa siswi SMA di Kab. kolaka pada kelompok kontrol pada saat pretest sebanyak $10(100 \%)$ responden mengalami flour albus dengan standart devisiasinya sebanyak 0,738 dan pada saat posttest pada kelompok kontrol terdapat $10(100 \%)$ responden tidak mengalami perubahan flour albus dan standart devisiasi pada kelompok kontrol posttest sebanyak 0,659

Hasil uji statistik dengan $U j i-t$ di peroleh nilai pada kelompok Eksperimen sebesar $\mathrm{p}=0,000(\mathrm{p}<0,05)$. Hal ini berarti $\mathrm{Ho}$ di tolak dan $\mathrm{Ha}$ diterima, artinya pemberian Ekstrak Minuman Lokal berpengaruh setelah diberikan intervensi terhadap penurunan tanda dan gejala flour albus pada siswi SMA di kab. kolaka. Dan pada kelompok kontrol diperoleh nilai sebesar $p=0,659 \quad(p<0,05)$. Hal ini berarti tidak ada pengaruh pada kelompok kontrol terhadap penurunan flour albus pada siswi SMA di Kab. Kolaka

Tabel 7 Kelompok Intervensi dan Kelompok Kontrol Pengaruh Konsumsi Minuman Lokal Terhadap Akne Vulgaris Pada Siswi SMA di Kab. Kolaka

\begin{tabular}{|c|c|c|c|c|c|c|c|c|c|}
\hline \multirow{3}{*}{$\begin{array}{c}\text { Ak } \\
\text { ne } \\
\text { Vul } \\
\text { gari }\end{array}$} & \multicolumn{3}{|c|}{ Eksperimen } & \multirow{2}{*}{$\mathrm{P}$} & \multicolumn{4}{|c|}{ Kontrol } & \\
\hline & Pre & $\mathrm{Po}$ & & & & $e$ & & st & \\
\hline & $\mathrm{n} \mid \%$ & $\mathrm{n}$ & $\%$ & & $\mathrm{n}$ & $\%$ & $\mathrm{n}$ & $\%$ & \\
\hline $\mathrm{Ya}$ & $10 \begin{array}{c}10, \\
0\end{array}$ & 3 & $\begin{array}{c}30, \\
0\end{array}$ & $\begin{array}{l}0,0 \\
01\end{array}$ & 10 & $\begin{array}{c}10 \\
0\end{array}$ & 10 & $\begin{array}{c}10 \\
0\end{array}$ & \\
\hline $\begin{array}{c}\text { ida } \\
\mathrm{k}\end{array}$ & \begin{tabular}{|c|c}
0 & 0,0 \\
0
\end{tabular} & 7 & $\begin{array}{c}70^{\prime} \\
0\end{array}$ & & 0 & 0 & 0 & 0 & \\
\hline
\end{tabular}


Tabel 7 Menunjukkan bahwa siswi SMA di Kab. kolaka pada kelompok eksperimen pada saat pretest sebanyak $10(100 \%)$ responden mengalami Akne vulgaris standart devisiasinya sebanyak 0,738 dan pada saat posttest pada kelompok eksperimen terdapat 7 $(70,0 \%)$ responden mengalami akne vulgaris dan ada 3 responden tidak mengalami akne vulgaris dan standart devisiasi pada kelompok posttest sebanyak 0,949

Sedangkan pada kelompok kontrol Menunjukkan bahwa Siswi SMA di Kab. kolaka pada kelompok kontrol pada saat pretest sebanyak $10(100 \%)$ responden mengalami Akne vulgaris dengan standart devisiasinya sebanyak 0,949 odan pada saat posttest pada kelompok kontrol terdapat $10(100 \%)$ responden tidak mengalami akne vulgaris dan standart devisiasi pada kelompok kontrol posttest sebanyak 1,252

Hasil uji statistik dengan Uji-t di peroleh nilai pada kelompok Eksperimen sebesar $p=0,001(p<0,05)$. Hal ini berarti Ho di tolak dan $\mathrm{Ha}$ diterima, artinya pemberian Ekstrak Minuman Lokal berpengaruh setelah diberikan intervensi minuman lokal terhadap Akne vulgaris pada siswi SMA di Kab. Kolaka. Dan pada kelompok kontrol diperoleh nilai sebesar $p=1,000 \quad(p<0,05)$. Hal ini berarti tidak ada pengaruh pada kelompok kontrol terhadap flour albus pada siswi SMA di Kab. Kolaka.

\section{PEMBAHASAN}

1. Pengaruh Konsumsi Minuman Lokal Terhadap tanda dan gejala flour albus

Pemberian minuman lokal di jadwalkan 8 minggu dengan jadwal pemberian 39 kali setiap responden. Lama konsumsi minuman lokal mempengaruhi hasil penelitian sebanyak 10 responden yang mengkonsumsi minuman lokal secara teratur ada 8 responden yang mengalami penurunan tanda dan gejala flour albus dan hanya 2 responden yang tidak mengalami penurunan tanda dan gejela flous albus.

Pemberian minuman lokal pada tahap satu (10 kali pemberian) responden belum merasakan adanya perubahan yang berarti sebagian besar responden masih beradaptasi dengan rasa dari minuman lokal yang dikonsumsi, Tahap kedua (10 kali pemberian) 3 responden merasakan adanya perubahan setelah mengkonsumsi minuman lokal, didapatkan jawaban dari responden Cairan (flour albus) mulai berkurang. Tahap ketiga (11 kali pemberian) ada 2 responden merasakan adanya perubahan setelah mengkonsumsi minuman lokal, didapatkan jawaban dari kedua responden yang mengatakan Cairan (flour albus) juga mulai berkurang. Tahap empat peneliti kembali memberikan intervensi sebanyak 8 kali pemberian minuman lokal ada 3 responden merasakan adanya perubahan setelah mengkonsumsi minuman lokal. total pemberian minuman lokal 39 kali dan ada 8 Responden yang minum secara teratur dengan hasil mengalami penurunan tanda dan gejala flour albus.

Ketiga buah ini Nangka, melon dan kersen memiliki kandungan Gizi (energy, karbohidrat, protein, Vitamin A,B, C, kalsium, Thiamin, Ribloflavin, Niacin, serat, air, kalium dan lemak). Sedangkan Vitamin A melindungi tubuh dari inveksi organisme asing seperti bakteri dan jamur Penyebab flour albus, Vitamin ini akan meningkatkan aktivitas kerja dari sel darah putih dan antibodi di dalam tubuh, sehingga tubuh menjadi lebih resisten terhadap senyawa toksin ataupun serangan mikroorganisme parasit. Maka ketika seseorang kekurangan vitamin A akan rentang terserang bakteri dan jamur yang bisa memicu terjadinya flour albus. 
Buah nangka melon kersen juga mengandung banyak vitamin $\mathrm{A}, \mathrm{B}$ dan $\mathrm{C}$ yang dapat menurunkan stress dan sebagaimana yang di ketahui bahwa stress merupakan factor resiko terjadinya flour albus.

Berdasarkan hasil penelitian yang telah dilakukan diperoleh hasil bahwa ada pengaruh stres terhadap keputihan dimana terdapat beberapa responden pada usai 16 tahun yang mengalami stres ini disebabkan kenakalan remaja, pengaruh negatif dan masalah akademis. Siswi dalam kegiatannya juga tidak terlepas dari stres. Stresor atau penyebab stres pada siswi dapat bersumber dari kehidupan akademiknya, terutama dari tuntutan eksternal dan tuntutan dari harapannya sendiri. Tuntutan eksternal dapat bersumber dari tugas-tugas pelajaran, beban pelajaran, tuntutan orang tua untuk mendapatkan prestasi dan penyesuaian sosial di lingkungan sekolahnya. Tuntutan ini juga termasuk kompetensi pelajaran dan meningkatnya kompleksitas materi pelajaran yang semakin lama semakin sulit. Tuntutan dari harapan siswi dapat bersumber dari kemampuan dalam mengikuti pelajaran.

Penelitian ini sesuai dengan teori yang dikemuakan oleh Maria (2009) mengatakan, bahwa penyebab terjadinya keputihan pada wanita juga dapat dipengaruhi oleh faktor stres. Hal ini terjadi karena ketika seseorang sedang stres, organ-organ dalam tubuh juga terpengaruh. Ketika otak mengalami stres ataupun kelelahan, otak yang mengontrol dan mengatur kinerja organ-organ dalam tubuh juga terpengaruh dan tidak bekerja dengan optimal.

Ketidakmaksimalan kemampuan otak untuk mengatur organ-organ dalam tubuh menyebabkan kemampuan organ-organ dalam tubuh menjadi terganggu. Produksi hormon yang ada dalam tubuh juga menjadi tidak seimbang sehingga dapat merangsang terjadi munculnya keputihan pada organ kewanitaan.

Menurut Supryanto (2010) menyatakan bahwa kondisi tubuh yang selalu tegang, cemas, kelelahan dan kurang istirahat dapat menimbulkan keputihan. Semua organ tubuh kinerjanya dipengaruhi dan dikontrol oleh otak, maka ketika reseptor otak mengalami kondisi stres, hal ini dapat menyebabkan terjadinya perubahan dan keseimbangan hormon-hormon dalam tubuh dan hal ini dapat menimbulkan terjadinya keputihan.

Sedangkan menurut Shadine (2009) kondisi tubuh yang kelelahan dan stres baik fisik maupun psikologis (seperti tuntutan akademis yang dinilai terlalu berat, hasil ujian yang buruk dan tugas yang menumpuk) dapat mempengaruhi kerja hormon-hormon yang ada dalam tubuh perempuan termasuk memicu peningkatan hormon estrogen. Pengaruh hormon estrogen ini menyebabkan terjadinya keputihan.

Berdasarkan hasil penelitian ini maka peneliti berasumsi bahwa stress dapat mempengaruhi keputihan dengan alasan dapat mempengaruhi kerja hormon-hormon yang ada dalam tubuh perempuan termasuk memicu peningkatan hormon estrogen. Pengaruh hormon estrogen ini menyebabkan terjadinya keputihan. Salah satu cara untuk mencegah keputihan menjaga kondisi tubuh dari kelelahan dan stres.

2. Pengaruh usia,terhadap akne vulgaris

Pada penelitian ini dari 20 sampel dibagi menjadi dua kelompok yaitu 10 sampel eksperimen dan 10 sampel kontrol. Dimana kelompok eksperimen diberikan minuman lokal yang terdiri dari serbuk nagka, melon, kersen yang di mix menjadi satu minuman lokal, Bersadarkan hasil pre test yang didapatkan dari 10 kelompok eksperimen terdapat $10(100,0 \%)$ Siswa SMA yang mengalami Akne Vulgaris dan pada post test $7(70,0 \%)$ siswi SMA mengalami penurunan tanda dan gejala 
akne atau gejala yang dialami lebih rendah dari sebelumnya. Berdasrkan hasil uji statistik dengan Npart-Test (uji-t) di peroleh nilai pada kelompok Eksperimen sebesar $\mathrm{p}=0,001(\mathrm{p}<0,05)$ yang artinya ada perbedaan yang sigtifikan antara kelompok eksperimen dan kelompok kontrol. kelompok kontrol diperoleh nilai sebesar $\mathrm{p}=1,000$ ( $>>0,05)$. Hal ini berarti tidak ada pengaruh pada kelompok kontrol terhadap akne vulgaris pada siswa SMA kab.Kolaka.

Pemberian minuman lokal di jadwalkan 8 minggu dengan jadwal pemberian 39 kali setiap responden. Lama konsumsi minuman lokal mempengaruhi hasil penelitian sebanyak 10 responden yang mengkonsumsi minuman lokal secara teratur ada 7 responden yang mengalami penurunan tanda dan gejala akne dan hanya 3 responden yang tidak mengalami penurunan tanda dan akne. Pemberian minuman lokal pada tahap satu (10 kali pemberian ) responden belum merasakan adanya perubahan yang berarti sebagian besar responden masih beradaptasi dengan rasa dari minuman lokal yang dikonsumsi, Tahap kedua (10 kali pemberian) belum ada responden merasakan adanya perubahan akne. Tahap ketiga (11 kali pemberian) ada 3 responden merasakan adanya perubahan setelah mengkonsumsi minuman lokal, didapatkan jawaban dari ke 3 responden yang mengatakan akne pada kulit wajah mulai berkurang. Tahap ke empat peneliti kembali memberikan intervensi sebanyak 8 kali pemberian minuman lokal ada 4 responden merasakan adanya perubahan setelah mengkonsumsi minuman lokal. total pemberian minuman lokal 39 kali dan ada 7 Responden yang minum secara teratur dengan hasil mengalami penurunan Akne vulgaris.

Ketiga buah ini Nangka, melon dan kersen memiliki kandungan Gizi (energy, karbohidrat, protein, Vitamin
A,B, C, kalsium, Thiamin, Ribloflavin, Niacin, serat, air, kalium dan lemak).

Vitamin $\mathrm{C}$ juga membantu mempercepat proses penyembuhan dan membantu tubuh melawan berbagai macam penyakit. vitamin $\mathrm{C}$ juga berfungsi sebagai pembentuk jaringan ikat serta membantu perkembangan sel, selain itu vitamin $\mathrm{C}$ juga berfungsi mencerahkan dan dan memperbaiki kerusakan kulit

Menurut teori dalam Suryadi RM (2008) yang menyatakan bahwa hampir setiap orang pernah mengalami Akne vulgaris dan biasanya dimulai ketika pubertas, dari survey di kawasan Asia Tenggara terdapat $40-80 \%$ kasus Akne vulgaris sedangkan menurut catatan studi dermatologi kosmetika Indonesia menunjukan yaitu $60 \%$ penderita akne vulgaris pada tahun $2006,80 \%$ terjadi pada tahun 2007 dan $90 \%$ pada tahun 2009. Prevelansi tertinggi yaitu pada umur 14-17 tahun, dimana pada wanita berkisar $83-85 \%$ dan pada pria yaitu pada umur 16-19 tahun berkisar 95$100 \%$. Pada umumnya banyak remaja yang bermasalah dengan Akne vulgaris.

Sedangkn menurur Smith $\mathrm{R}$ dkk (2007) menyatakan bahwa penyebab Akne vulgaris sangat banyak (multifaktorial), antara lain faktor genetik, faktor bangsa ras, faktor makanan, faktor iklim, faktor jenis kulit , faktor kebersihan, faktor penggunaan kosmetik, faktor stress, faktor infeksi dan faktor pekerjaan. Tingkat pendidikan yang rendah mengakibatkan kurangnya pengetahuan seseorang dalam menghadapi masalah, sedangkan remaja yang mempunyai tingkat pendidikan yang kurang dalam menjaga pola hidup yang baik. Suatu proses pertumbuhan dan perkembangan manusia, usaha mengatur pengetahuan semula yang ada pada seorang individu serta pendidikan juga menjadi tolak ukur yang penting dalam perubahanperubahan perilaku yang positif. Dengan pendidikan tinggi, maka 
wawasan pengetahuan semakin bertambah dan semakin menyadari bahwa begitu pentingnya kesehatan bagi kehidupan sehingga termotivasi untuk melakukan kunjungan ke pusat pelayanan kesehatan yang lebih baik.

\section{SARAN}

1. Bagi siswi SMA disarankan agar berolahraga secara teratur dan mangatur pola konsumsi untuk flour albus dan akne vulgaris

2. Bagi siswa sebaiknya menjaga kebersihan daerah genitalianya agar terhindar dari factor resiko flour albus,

3. Bagi Siswi SMA mengatur Pola makan disarankan untuk mengurangi konsumsi yg manis-manis dan juga makanan yang banyak mengandung minyak. dan juga senantiasa menjaga kebersihan wajah terutama tidak lupa mencuci muka ketika sepulang sekolah. karena berdasarkan bukti bahwa konsumsi dan kebersihan yang tidak di jaga dapat meningkatkan risiko

4. Diharapakan kepada sekolah untuk memberikan pembelajaran kepada siswa tentang bagaimana menjaga kesehatan.

\section{DAFTAR PUSTAKA}

Adhi juanda, 2010.ilmu penyakit kulit da kelamin.jakarta. fakultas kedokteran universitas indinesia.

Arief.P.S.2010. Agribisnis melon. Jawa barat: pustaka gravika

Ayu. B. Nurul.P dan Fajar.2013 Ilmu Gizi untuk praktisi kesehatan. Yogyakarta : Graha Ilmu

Deissy marcelien, 2013 .hubungan antara pengetahuan dan prilaku remaja putri dalam menjaga kebersihan alat genitalia dengan kejadian keputihan. Naskah publikasi. Di akses 20 januari 2017.
Egi yunita, 2012. faktor prilaku yang mempengaruhi kejadian keputihan pada remaja putri. Di akses 21 januari 2017.

Koes irianto, 2015.kesehatan reproduks teori dan praktikumi.bandung. alfabeta.

Nanang. M. 2010. Metode penelitian kuantitatif. Jakarta : PT. Rajagrafindo Persada

Noor azizah,2015.karakteristik remaja putri dengan kejadian keputihan di smk muhammadiyah kudus.di akses 20 januari 2017.

Rizqun nisa. 2015. akne vulgaris pada remaja naskah publikasi. Di akses 20 Januari 2017

Siti komariah, edi sucipto.2015. gambaran pengetahuan remaja putri tentang keputihan. Naskah publikasi. Di akses 20 januari 2017

Shedine,2012.kesehatan reproduksi wanita. Di akses 20 Januari 2017.

Saryono. 2011. Metodologi Penelitian Kesehatan. Jakarta : Mitra Cendikia.

Sugiyono. 2015. Metode penelitian kuantitatif kualitatif dan $R \& D$. Bandung : Alfabeta.

Susilo, H. W., \& Aima. H. M. 2013. Penelitian Dalam Ilmu Keperawatan: Pemahaman Dan Penggunaan Metode Kuantitatif Serta Aplikasi Dengan Program SPSS \& Lisrel. Jakarta : In Media.

Soekidjo. N. 2012. Metode penelitian kesehatan. Jakarta : PT. Rineka Cipta.

Volume VIII No 2 Edisi Desember 2015 ISSN: 19779-469X 
